\title{
Design flood assessment on the upper Rhine using historical data and accounting for discharge uncertainty
}

\author{
Lang M. ${ }^{1}$, Le Coz J. ${ }^{1}$, Renard B. ${ }^{1}$, Darienzo M. ${ }^{1}$ \\ ${ }^{1}$ INRAE, RIVERLY Research Unit, Lyon-Villeurbanne, France
}

\begin{abstract}
Design floods on the upper Rhine River are a major issue for French-German agreements on flood embankments. As intense river training has modified the Rhine River morphology during the 19th century, with a significant rectification of the river course, some disagreement does exist on the interest and value of including information on historical floods. Some hydrological studies are using discharge series from the 20th century only, arguing that it is not possible to estimate flood discharge correctly during and before the river works of the 19th century. Other studies include a set of large historical floods during the 19th century. Unfortunately, design flood estimates with or without historical information are significantly. We used two long discharge series in Basel-Switzerland (1808-2018, with a set of historical floods since 1268) and Maxau-Germany (1815-2018). A preliminary analysis allowed crossing different archive sources, correcting data to account for the main river corrections (1714 and 1890), checking the homogeneity of data and assessing the uncertainty of the stage-discharge relationship. We present a comparative study of design floods with several distributions and several series lengths (a few decades to several centuries). A statistical Bayesian framework allows comparing design floods and the corresponding uncertainties.
\end{abstract}

\section{French-German agreement of flood embankment on the upper Rhine River}

The upper Rhine is the section of the Rhine located between Basel-Switzerland and Bingen-Germany. The upper Rhine Plain, or upper Rhine Graben, was settled for many centuries and was frequently damaged by Rhine floods, both in France and Germany. This led to rectification works, initially at a small scale (Middle Age) for repair works after floods, then at a large scale (19th and 20th centuries) for channelling works. The FrenchGerman convention of $4^{\text {th }}$ July 1969 states that the riverbanks of the Rhine river should not be flooded by a design discharge $Q^{*}=7500 \mathrm{~m}^{3} / \mathrm{s}$, at the end of the FrenchGerman section of the river (Iffezheim). Therefore statistical analyses aimed to assess the corresponding return period related to the $Q^{*}$ discharge. A French study (EDF, 2002) used annual maximum discharge (19332000) and a set of six historical floods from 1802 to 1932 in Basel. A German study (IWG, 2010) used discharge series from the 20th century only, arguing that it is not possible to estimate flood discharge correctly during and before the river works of the 19th century. The return period $T\left(Q^{*}\right)$ varies from 1000 to more than 10000 years according to the French or German studies.

We present here the results of a flood frequency analysis on extreme floods (Lang, 2021), accounting for discharge uncertainties, which may be different for recent and past floods. Section 2 presents the two long discharge series in Basel-Switzerland (1808-2018, with a set of historical floods since 1268) and Maxau-Germany (18152018). Discharge uncertainty of annual maximum discharge is estimated with the BaRatin model (section 3) and discharge distribution is estimated with the HBay model (section 4). Section 5 concludes on the risk of overflowing of the Rhine River in the end of the FrenchGerman section of the river.

\section{Long discharge series in Basel- Switzerland and Maxau-Germany}

\subsection{Hydrometric data in Basel-Switzerland}

The first systematic stage records were carried out in Schifflände from 1808 to 1994 and are available in Rheinhalle from 1974 to today (Figure 1). Flood flows have been available continuously since 1808.70 gauges were carried out over the period 1867-1933 and 90 gauges over the period 1994-2018; there are nine rating curves for the period 1916-1932 and 25 rating curves for the period 1986-2018. The catchment area of the Rhine river is $35930 \mathrm{~km}^{2}$ (resp. $35925 \mathrm{~km}^{2}$ ) in Schifflände (resp. Rheinhalle). It is located on the course of the Rhine at kilometer point KP 166.7 (resp. KP 164.39). The stage measurements of the Rhine hydrometric station in Schifflände were under downstream influence from the commissioning of the Kembs dam in 1933. This led the

a Corresponding author: michel.lang@inrae.fr

DOI 10.3311/FLOODRisk2020.3.6 
managers of the gaging station to estimate the discharge of the Rhine river in Basel over the period 1933-1994 from the Rhine station in Rheinfelden further upstream (KP 148.05) and from the flow of the two tributaries (Birs and Ergolz), or from the Saint-Alban station (1945-1983) (located between Schifflände and Rheinhalle). The Rhine station in Rheinhalle officially took over from that in Schifflände from 1995, although discharge data have been available since 1904 (BAFU, 2021).

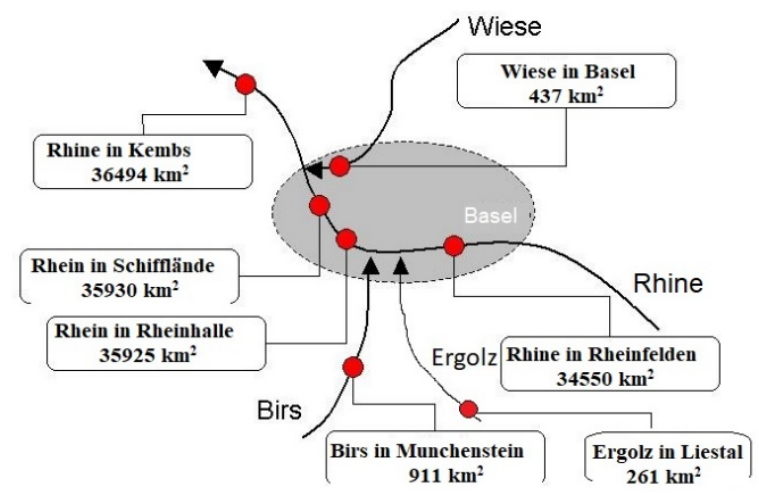

Figure 1. Location of the gaging station of Basel-Switzerland

A detailed inventory of the largest floods of the Rhine river in Basel is available from twelve flood marks (16411881) on the Schönbeinhaus (93 Oberer Rheinweg, about $500 \mathrm{~m}$ upstream from Schifflände, on the right bank) and from documentary data describing extreme flooding events on the old Town of Basel since 1268 (Wetter et al., 2011). Based on a hydraulic model, Wetter et al. (2011) identified a data set of 38 floods before 1808: 27 floods with a peak discharge greater than $4911 \mathrm{~m}^{3} / \mathrm{s}$ on $1268-1713$ and 11 floods with a peak discharge greater than $4322 \mathrm{~m}^{3} / \mathrm{s}$ on 1714-1807.

The High Rhine, upstream to Basel, was the subject of major hydraulic works in the 18th and 19th centuries, which significantly modified the flood routing. This requires correcting the old values in the current hydraulic context in order to have a homogeneous series.

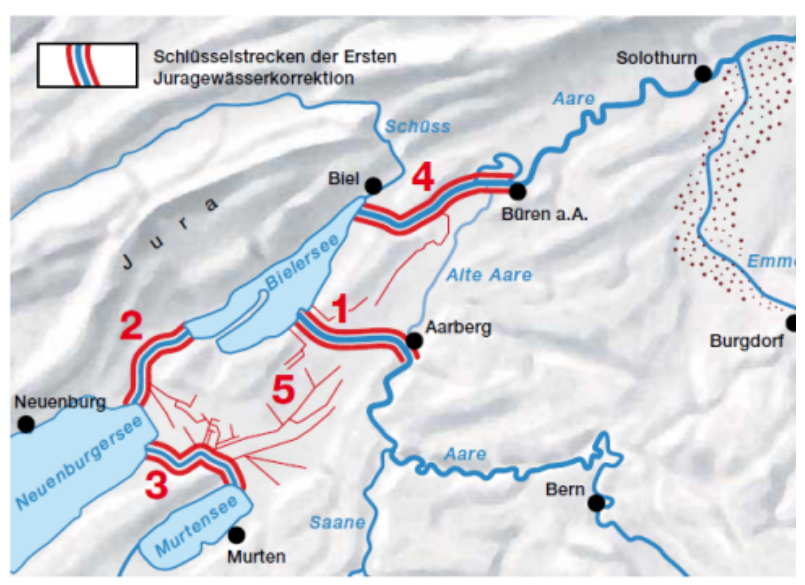

Figure 2. First "water correction works in the Jura" over the period 1868-1891: 1. Diversion of the River Aare into Lake Bienne; 2-3-4. Upstream/downstream lake correction works; 5. Marshland drainage (source: https://www.bve.be.ch/bve/de/ index/wasser/wasser/juragewaesserkorrektion.html)
First, there was the diversion of a tributary of the Aar, the Kander, into Lake Thun in 1714. The effect of this river work was estimated by Wetter et al. (2011) using a hydraulic model. Before 1714, all floods greater than 4911 $\mathrm{m}^{3} / \mathrm{s}$ in Basel have to be reduced by $270 \mathrm{~m}^{3} / \mathrm{s}$ to take into account the effects of the Kander diversion if the floods had occurred in the current state.

Second, there were the first "water correction works in the Jura" over the period 1868-1891 (Figure 2). They consisted in diverting the course of the Aar to pass it through Lake Biel (Bielersee) and increasing the exchange capacities between this lake and the lakes of Neuchatel

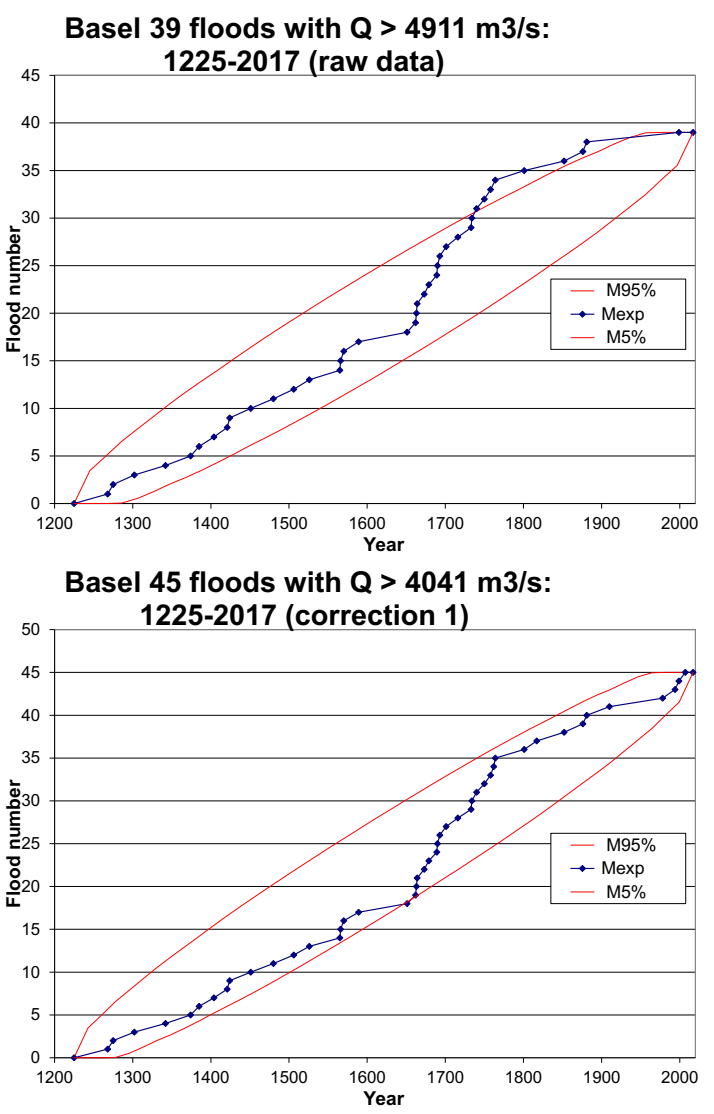

Basel 56 floods with $Q>3569 \mathrm{~m} 3 / \mathrm{s}$ :

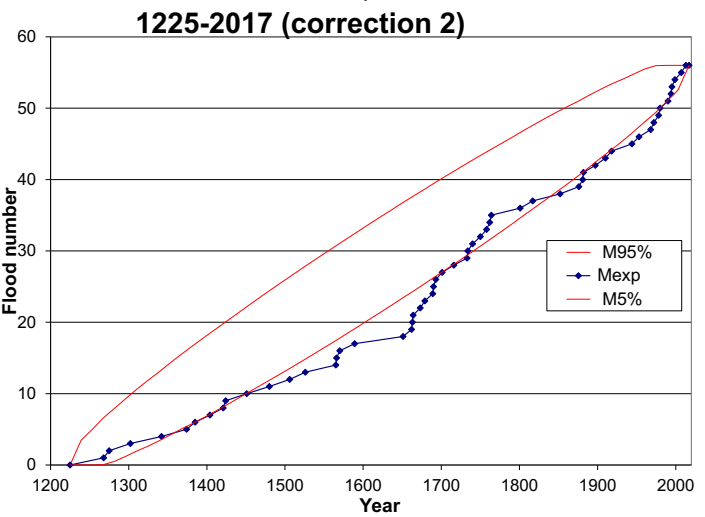

Figure 3. Poisson test on the largest known floods in Basel over the period 1225-2017. The first catastrophic flood dates back from 1268, whereas the period starts in 1225, date of building of the first city's bridge (Wetter et al., 2011) 
(Neuenburgersee) and Morat (Murtensee). The impact of this work was significant and was the subject of hydraulic studies by Wetter et al. (2011) and CECR (1978), with respectively corrections $\mathrm{n}^{\circ} 1$ and 2 . The lamination effect is starting from a discharge of $2600 \mathrm{~m}^{3} / \mathrm{s}$. It increases up to $600 \mathrm{~m}^{3} / \mathrm{s}$ for the last study (correction $\mathrm{n}^{\circ} 1$ ) and up to 1300 $\mathrm{m}^{3} / \mathrm{s}$ (correction $\mathrm{n}^{\circ} 2$ ) for the oldest one.

We present a comparison of a homogeneity test on several data series, with raw data, or corrected data (correction $\mathrm{n}^{\circ} 1$ and 2). Assuming a Poisson process, the experimental curve of the cumulative number of peak-over threshold values versus time should be within the limits of the confidence interval (Lang et al., 1999). Considering the largest known floods from the 1225-2017 period, figure 3 shows that the Basel series is heterogeneous without correction or with correction $n^{\circ} 2$, as it becomes homogeneous with correction $n^{\circ} 1$.

Using the correction $\mathrm{n}^{\circ}$, we apply a segmentation procedure (Darienzo et al., 2021) on the annual maximum floods from 1808 to 2017. This method accounts for observational discharge uncertainties and expresses change points in terms of time (rather than position). Figure 4 shows a shift located on the 1966-1976 period, which was already detected by IWG (2010). All peak flows before 1977 have been incremented of $+150 \mathrm{~m}^{3} / \mathrm{s}$, in order to have a homogeneous series.

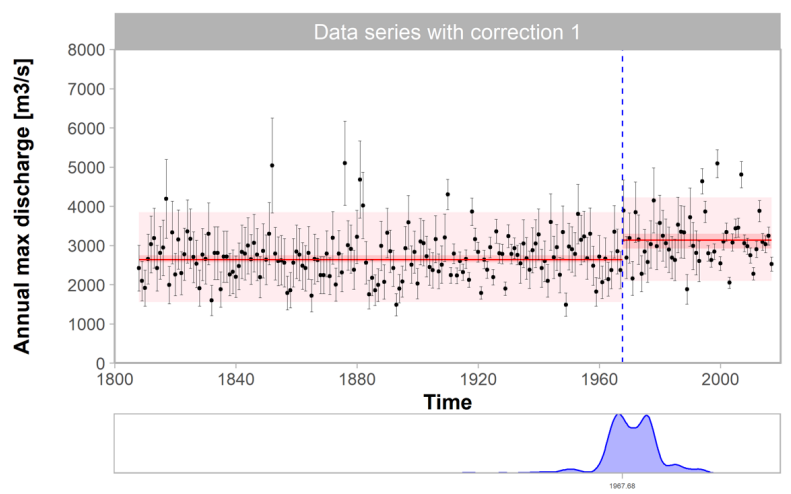

Figure 4. Darienzo's segmentation procedure applied to annual maximum floods in Basel over the period 1808-2017 (data with correction $\mathrm{n}^{\circ} 1$ ). Total (pink) and parameter (red) uncertainty at $95 \%$ level of each segment mean

\subsection{Hydrometric data in Maxau-Germany}

The first systematic stage records were carried out since 1815. According to WSV (1975), stage was first manually observed over the period 1815-1896 (from 1 to 3 times a day depending on the period). The first float gage was installed in 1888 and operational since 1897. Due to the Second World War, measurements were interrupted several times over the period May 1942-November 1943, and the gaging station was destroyed in November 1943. A new stage recorder was installed at the end of February 1946. Flood flows have been available continuously since 1821. About 850 gauges have been carried out since 1947 and 37 rating curves have been established over the period 1821-2018. The catchment area of the Rhine river is $50343 \mathrm{~km}^{2}$ in Maxau. It is located on the course of the Rhine at kilometer point KP 362.33.
The shape of the river was heavily modified with the rectification of the Rhine River: meander correction 18151831, Tulla's river engineering 1843-1860, regulation works 1906-1924 and 1930-1939, channelling 1928-1977, retention areas 1982-2018. Based on hydraulic simulations (CECR, 1978; LUBW, 2019), all floods have been corrected to the same reference state in 1977. Figure 5 shows a shift in 1977, which was already detected by IWG (2010). Like Basel, we corrected peak flows before 1977 with an increment of $+150 \mathrm{~m}^{3} / \mathrm{s}$, in order to have a homogeneous series. Further studies are needed to explain this similar change of $+150 \mathrm{~m}^{3} / \mathrm{s}$ in both stations.

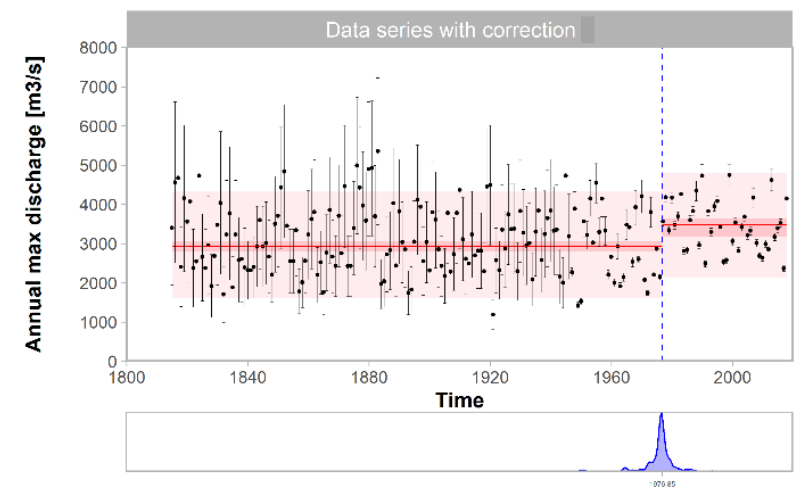

Figure 5. Darienzo's segmentation procedure applied to annual maximum floods in Maxau over the period 1815-2018 (data corrected for the same reference configuration in 1977)

\section{Assessment of discharge uncertainty with the BaRatin model}

\subsection{BaRatin model}

The BaRatin model (Le Coz et al., 2014) combines, via a Bayesian approach, an expertise on the hydraulic controls that govern the stage-discharge relation, with the available gauging data $\left(H_{i}, Q_{i}\right)$. The method provides an estimate of the $Q(H)$ rating curve, and the associated uncertainties. The elicitation of hydraulic priors is based on the identification of elementary hydraulic controls: control type (channel, section) and associated parameters (geometry and roughness). Gauging uncertainty is assumed from the type of gaging (point velocity or velocity area) and the type of sensor (acoustic profiler, current meter, tracer dilution, radar velocimeter...).

\subsection{Discharge uncertainty on Rhine River in Basel}

Using hydrometric data in Basel (section 2.1) and topographic surveys of the cross section and longitudinal profiles since 1830 , we apply the BaRatin model. Table 1 summarizes the multiplicative errors on the rating curve, which vary from $\pm 7 \%(1994-2017)$ to $\pm 19 \%$ (1867-1909). 


\begin{tabular}{|l|c|c|c|c|c|c|}
\hline Period & $\begin{array}{c}1225- \\
1807\end{array}$ & $\begin{array}{c}1808- \\
1866\end{array}$ & $\begin{array}{l}1867- \\
1909\end{array}$ & $\begin{array}{c}1910- \\
1933\end{array}$ & $\begin{array}{c}1934- \\
1993\end{array}$ & $\begin{array}{c}1994- \\
2017\end{array}$ \\
\hline $\begin{array}{l}\text { Number of } \\
\text { gaugings }\end{array}$ & $/$ & $/$ & 10 & 60 & $/$ & 90 \\
\hline $\begin{array}{l}\text { Type of } \\
\text { gauging }\end{array}$ & $/$ & $/$ & ${ }^{(1)}$ & $(2)$ & $/$ & ${ }^{(3)}$ \\
\hline $\begin{array}{l}\text { Gauging } \\
\text { uncertainty }\end{array}$ & $/$ & $/$ & $\pm 20 \%$ & $\pm 15 \%$ & $/$ & $\pm 7 \%$ \\
\hline $\begin{array}{l}\text { Discharge } \\
\text { uncertainty }\end{array}$ & $\pm 40 \%$ & $\pm 22 \%$ & $\pm 19 \%$ & $\pm 9 \%$ & $\pm 20 \%$ & $\pm 7 \%$ \\
\hline
\end{tabular}

Table 1. Discharge uncertainties on Rhine River in Basel. Type of gauging: ${ }^{(1)}$ surface float; ${ }^{(2)}$ surface current meter; ${ }^{(3)}$ acoustic profiler

As no gauging is available before 1867 , we used a retrospective approach. The posterior rating curve of the 1867-1909 period is a prior for the 1808-1866 period. Then, expanding the uncertainties of the geometry and roughness parameters and using longitudinal profiles of the Rhine river in 1830, 1852, 1895, 1902, 1926 (BWSK, 1930), we obtain an estimate of the rating curve of the 1808-1866 period and the associated uncertainties ( \pm $22 \%$ ). Figure 6 shows a good agreement between the estimated rating curve from a retrospective approach and three points (in red) corresponding to the overflowing discharge of three remarkable sites within the old town of Basel (Blumenplatz, Fischmarkt low and Fischmarkt high). Using a 1D hydraulic model, Wetter et al. (2011) reconstructed the discharge $Q\left(4300 ; 4900 ; 6400 \mathrm{~m}^{3} / \mathrm{s}\right)$ associated to each altitude $Z(249.6 ; 250.1 ; 251.1 \mathrm{~m})$. The rating curve of the $1225-1807$ period is more uncertain $( \pm$ $40 \%$ ) as the river morphology may have changed.

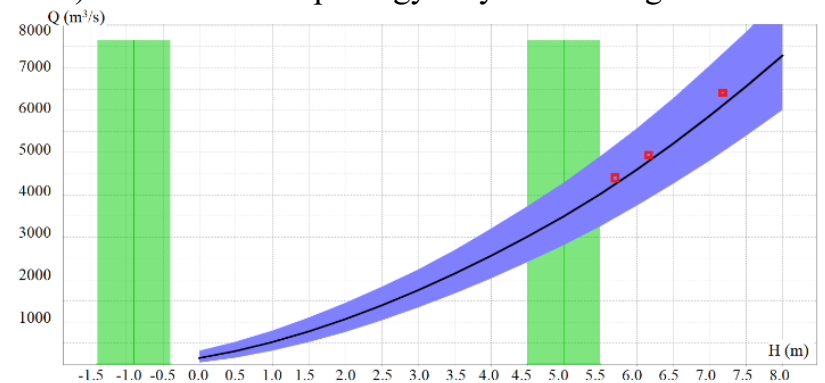

Figure 6. Rating curve of the Rhine River in Basel-Schifflände, period 1808-1866. Three points in red from Wetter et al.

(2011); altitude of the zero scale is $Z_{0}=243.90 \mathrm{~m}$

\subsection{Discharge uncertainty on Rhine River in Maxau}

The same approach with hydrometric data in Maxau (section 2.2) and information of the morphological changes during the two last centuries (BWSK, 1885 and 1930) gives an estimate of rating curve uncertainties. Table 2 shows that the multiplicative errors on the rating curve vary from $\pm 3 \%$ (1969-2018) to $\pm 42 \%$ (1815-1839).

\begin{tabular}{|l|c|c|c|c|}
\hline Period & $\begin{array}{c}1815- \\
1839\end{array}$ & $\begin{array}{c}1840- \\
1946\end{array}$ & $\begin{array}{c}1947- \\
1968\end{array}$ & $\begin{array}{c}1969- \\
2018\end{array}$ \\
\hline $\begin{array}{l}\text { Number of } \\
\text { gaugings }\end{array}$ & $/$ & $/$ & 64 & 784 \\
\hline $\begin{array}{l}\text { Type of } \\
\text { gauging }\end{array}$ & $/$ & $/$ & $(1)$ & $(1)(2)$ \\
\hline $\begin{array}{l}\text { Gauging } \\
\text { uncertainty }\end{array}$ & $/$ & $/$ & $\begin{array}{c} \pm 10 \text { to } \\
20 \%\end{array}$ & $\begin{array}{c} \pm 5 \text { to } \\
20 \%\end{array}$ \\
\hline $\begin{array}{l}\text { Discharge } \\
\text { uncertainty }\end{array}$ & $\pm 42 \%$ & $\pm 32 \%$ & $\pm 5 \%$ & $\pm 3 \%$ \\
\hline
\end{tabular}

Table 2. Discharge uncertainties on Rhine River in Maxau. Type of gauging: ${ }^{(1)}$ current meter; ${ }^{(2)}$ acoustic profiler

\section{Flood Frequency Analysis}

\subsection{HBAY flood model}

We use the HBAY model, based on the methodology described by Neppel et al. (2010). It accounts for multiplicative errors on discharge data $\mathbf{y}$, which may be variable according to the date (see tables 1 and 2). The parameters $\boldsymbol{\theta}$ of the distribution of $\mathbf{y}$ are fitted through a Bayesian framework with MCMC simulations:

$$
p(\boldsymbol{\theta} \mid \boldsymbol{y}) \propto L(\boldsymbol{y} \mid \boldsymbol{\theta}) p(\boldsymbol{\theta})
$$

where $L(\mathbf{y} \mid \boldsymbol{\theta})$ is the likelihood of the data $\mathbf{y}$, and $p(\boldsymbol{\theta})$ a prior on the parameters $\boldsymbol{\theta}$. As explained by Renard et al. (2013), we consider:

- the modal parameter estimate $\theta *$ which maximizes the posterior distribution $p(\boldsymbol{\theta} \mid \boldsymbol{y})$;

- a posterior $95 \%$ credibility interval of quantile $y_{p}$ which does correspond to the 2.5 and $97.5 \%$ quantiles from the posterior distribution of $y_{p}$;

- the predictive distribution $p(z \mid \boldsymbol{y})$ of a value $\mathbf{Y}=z$, defined as:

$$
p(z \mid \boldsymbol{y})=\int p(z \mid \boldsymbol{\theta}) p(\boldsymbol{\theta} \mid \boldsymbol{y}) d \boldsymbol{\theta}
$$

\subsection{Choice of a flood distribution}

For the period after the main major hydraulic works of the $19^{\text {th }}$ century (see sections 2.1 and 2.2), we compare the flood distributions in Basel (1903-2017) and Maxau (1891-2018). Figure 7 shows that the Gumbel distribution overestimates the experimental distribution, both in Basel and Maxau, and the LogNormal distribution is not adapted to Maxau. We will further use only the GEV distribution, which encompasses the Gumbel distribution. 


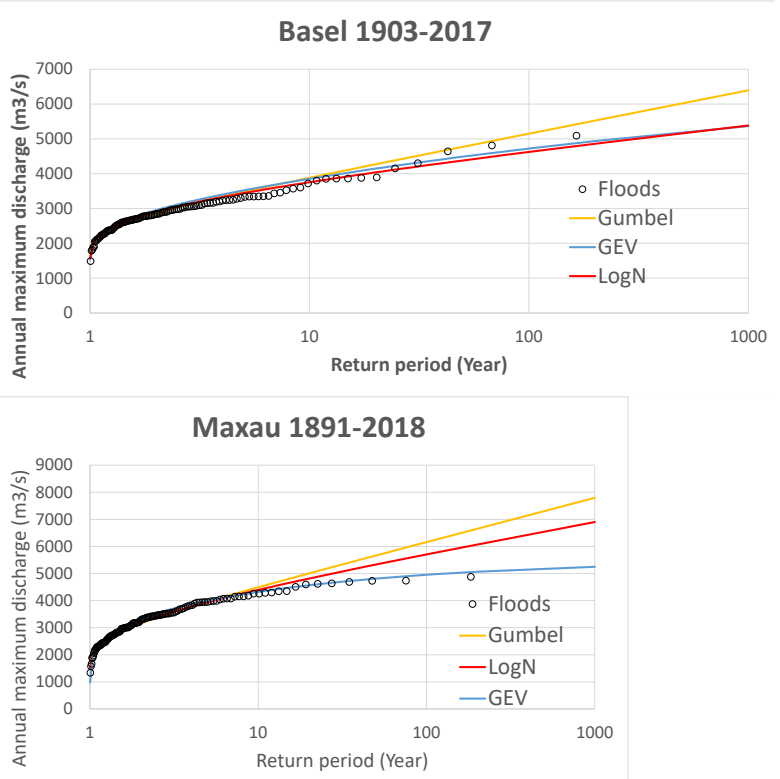

Figure 7. Comparison of Gumbel, LogNormal and GEV distributions of the annual maximum discharge: Basel (19032017) and Maxau (1891-2018)

\subsection{Interest of historical data}

In Basel, we consider four data sets:

- 1903-2017 period used by IWG (2010). Annual maximum floods have small uncertainties, about $\pm 10 \%$, except the $1934-1993$ period;

- 1808-2017 period, with the full continuous record. Additional annual maximum floods have larger uncertainties, about $\pm 20 \%$;

- 1714-2017 period, adding 11 historical floods larger than $4322 \mathrm{~m}^{3} / \mathrm{s}$. Historical floods have large uncertainties, about $\pm 40 \%$;

- 1268-2017 period, adding 27 historical floods before the Kander diversion in 1714 and larger than 4911 $\mathrm{m}^{3} / \mathrm{s}$. Historical floods have large uncertainties, about $\pm 40 \%$.

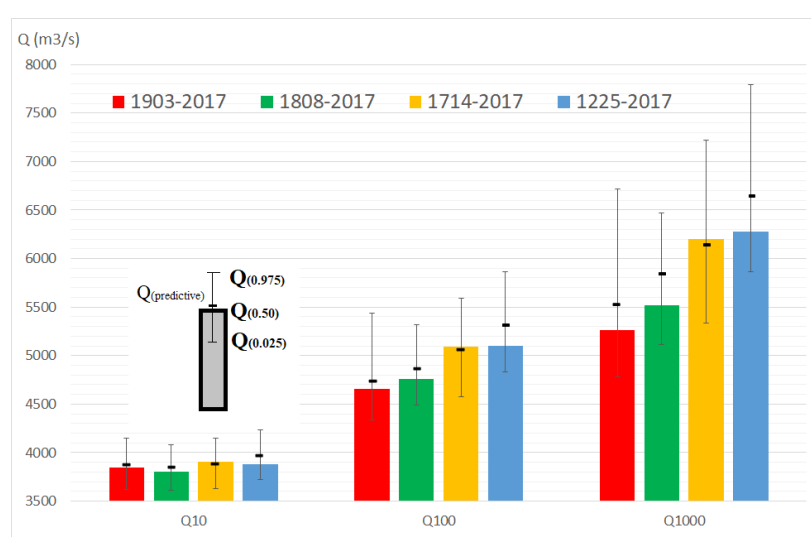

Figure 8. Comparison of $Q 10, Q 100$ and $Q 1000$ flood quantiles in Basel with four data sets since 1903, 1808, 1714 and 1268

Figure 8 shows a comparison between flood quantiles. Differences remain small, less than $5 \%$ using one or two centuries of annual maximum floods. Adding historical floods induces a slight increase of quantiles ( \pm 7 to $20 \%$ ).
An interesting result is that the uncertainty remains globally stable, about \pm 13 to $15 \%$ for $Q 100$, and \pm 20 to $33 \%$ for $Q 1000$. It was not obvious, as two opposite effects may interfere. On the one hand, large series have the potential to reduce sampling uncertainty. On the other hand, adding historical floods with larger uncertainty may increase the quantile uncertainty.

In Maxau, we consider three data sets:

- $1947-2018$ period. Annual maximum floods have very small uncertainties, less than $\pm 5 \%$, due to 850 gaugings;

- 1891-2018 period used by IWG (2010). Additional annual maximum floods have large uncertainties, about $\pm 30 \%$, due to the lack of gauging;

- 1815-2018 period, with the full continuous record. Additional annual maximum floods have large uncertainties, about $\pm 40 \%$, due to the lack of gauging and morphological changes.

Figure 9 shows that flood quantiles increase with the length of the series, \pm 5 and $10 \%$ for $Q 100$, and \pm 7 to $16 \%$ for $Q 1000$. The uncertainty with the $1947-2018$ period is $\pm 24 \%$ for $Q 100$ and $\pm 35 \%$ for $Q 1000$. An interesting result is that it decreases by adding flood information before 1947: $\pm 18-19 \%$ for $Q 100, \pm 26-27 \%$ for $Q 1000$.

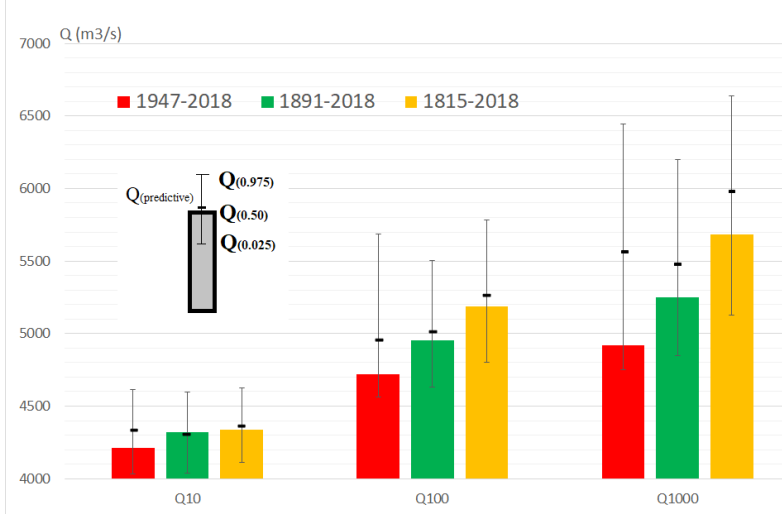

Figure 9. Comparison of $Q 10, Q 100$ and $Q 1000$ flood quantiles in Maxau with three data sets since 1947, 1891 and 1815

\subsection{Risk of overflowing of the Rhine River in Iffezheim}

Figure 10 shows that the flood distributions in Basel and Maxau may cross beyond a 1000 year return period. The main reason is the value of the shape parameter $k$ of the GEV distribution. A value close to zero $(k=0.066)$ in Basel induces a Gumbel distribution, as a significant positive value $(k=0.219)$ in Maxau induces a Weibull distribution with an upper limit. 


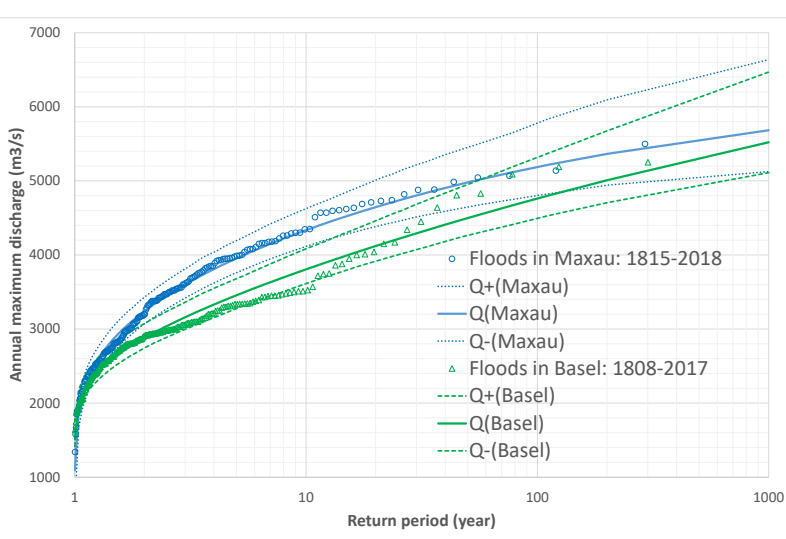

Figure 10. GEV distribution of the annual maximum flood in Basel (1808-2017) and Maxau (1815-2018), with 95\% credibility interval

We perform a new computation of the two distributions, assuming a regional prior distribution on $k$, within the interval $[-0.1 ; 0.4]$. It corresponds to the range of $k$ values in Basel and Maxau. The posterior distributions of $k$ are less different (Figure 11).

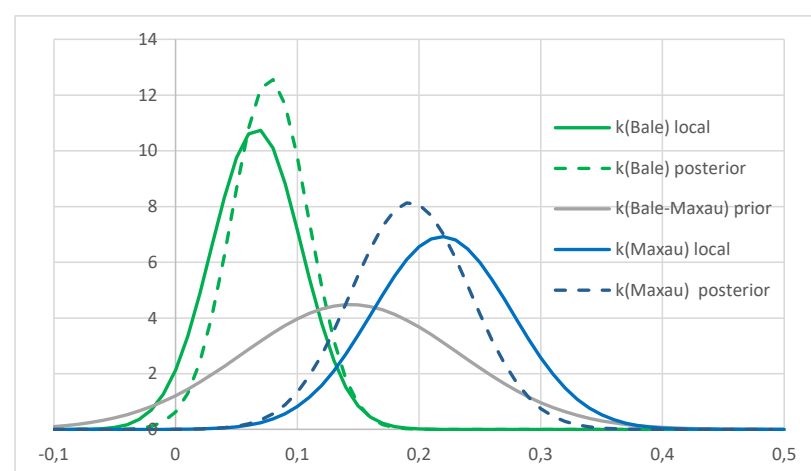

Figure 11. Distributions of the shape GEV parameter in Basel (1808-2017) and Maxau (1815-2018): local distributions (solid lines), regional prior (grey line), posterior distributions (dashed lines)

Figure 12 shows a good coherency from upstream (Basel) to downstream (Maxau). As the return period of the design discharge $Q^{*}=7500 \mathrm{~m}^{3} / \mathrm{s}$ should be estimated in Iffezheim (46 $400 \mathrm{~km}^{2}$ ), between Basel (35 $925 \mathrm{~km}^{2}$ ) and Maxau (50 $343 \mathrm{~km}^{2}$ ), we interpolate by assuming a power law relationship between flood quantile and catchment area.

The design discharge $Q^{*}$ has a very low exceedance probability, less than $10^{-4}$. As the required level of protection of the Rhine's riverbanks is $0.710^{-3}$ to $10^{-3}$ (France; Germany), we can conclude that the present situation is acceptable.

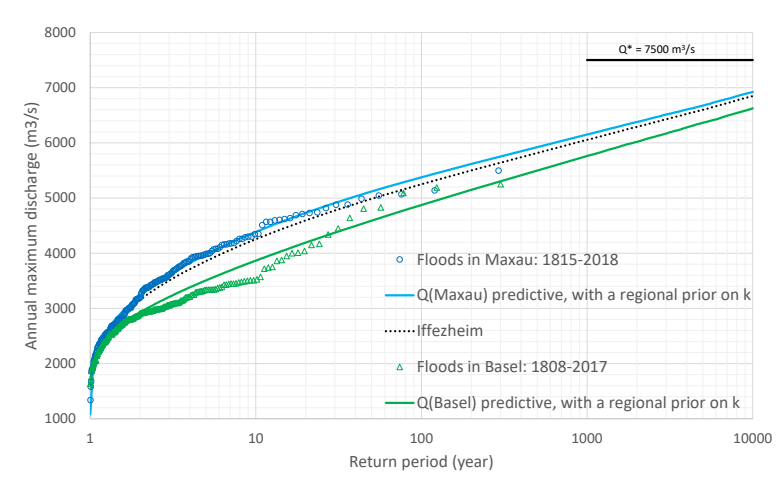

Figure 12. GEV predictive distribution of the annual maximum flood in Basel (1808-2017) and Maxau (1815-2018), using a regional prior on the shape parameter. Interpolation of flood quantiles in Iffezheim

\section{Conclusion}

This new reassessment benefits from an extended data set with two long discharge series of two centuries in Basel (1808-2017) and Maxau (1815-2018). The previous study from IWG (2010) did not use any flood before 1891, and the study from EDF (2002) used only 74 floods over the 1802-2000 period.

A detailed uncertainty analysis on rating curves used gauging information when available and prior estimation of geometry and roughness parameters. "Modern" floods have a low discharge uncertainty $( \pm 5-7 \%$, Maxau-Basel $)$, as "historical" flood discharges are more uncertain $( \pm 20$ 40\%; Basel-Maxau).

A Bayesian analysis accounting for discharge errors allowed assessing the value of historical data. Despite historical floods are less known than "modern" floods, the final uncertainty on flood quantiles lowers by adding floods from the $19^{\text {th }}$ century. It enhances the diagnosis on the safety of the Rhine riverbank at the end of the FrenchGerman section of the river. Elevation of riverbank is higher than the required target, which does correspond to a 1000-year flood.

\section{References}

1. BAFU (2021). Stationsgeschichte Rhein-Basel. History of Rhein-Basel gaging station, https://www.hydrodaten.admin.ch/fr/2289.html (in German), 7p.

2. BWSK (1885). Beitrage zur Hydrographie des Grossherzogthums Baden. Atlas zum dritten Heft. Contributions to the hydrography of the Grand Duchy of Baden. Atlas. OberDirecktion des Wasser und Strassenbaues, Karlsruhe (in German), 12 plates.

3. BWSK (1930). Die Veranderungen im Langenschnitt des Rheins zwischen Basel and Mannheim seit dem Jahr 1830. Changes in the elevation of the Rhine from Basel to Mannheim in the years 1810 to 1927 . Bad Wasser und Strassenbaudirektion in Karlsruhe (in German), 111p.

4. CECR (1978). Résultat des études sur les crues du Rhin et incidences de l'aménagement du Rhin. Results 
of flood studies on the Rhine River and impact of hydraulic correction of the Rhine. Commission d'Etude des Crues du Rhin (bilingual French and German), 55p.

5. Darienzo M., Renard B., Le Coz J., Lang M. (2021). Detection of stage-discharge rating shifts using gaugings: A recursive segmentation procedure accounting for observational and model uncertainties. Water Resources Research, in revision.

6. EDF (2002). Calcul du débit millénal à Fessenheim par la méthode du renouvellement dans le cadre de la réactualisation de la CMS du site. Design flood estimate by renewal method in Fessenheim (in French), 31p.

7. IWG (2010). Ermittlung von extremen Abflüssen für die Staustufen Gambsheim und Iffezheim. Extreme value analysis in Gambsheim and Iffezheim. Univ. of Karlsruhe (in German), 49p.

8. Lang M. (2021). Expertise sur l'hydrologie du Rhin sur les biefs de Gambsheim et Iffezheim. Hydrological expertise on Rhiner River in Gambsheim and Iffezheim. INRAE (bilingual French and German), $101 \mathrm{p}$.

9. Lang M., Ouarda T., Bobée B. (1999).Towards operational guidelines for over-threshold modelling. Journal of Hydrology, 225, 103-117, doi: 10.1016/S0022-1694(99)00167-5

10. Le Coz J., Renard B., Bonnifait L., Branger F., Le Boursicaud R. (2014). Combining hydraulic knowledge and uncertain gaugings in the estimation of hydrometric rating curves: A Bayesian approach. Journal of Hydrology, 509, 573-587, doi: 10.1016/j.jhydrol.2013.11.016

11. LUBW (2019). Bisherige Retentionseinsätze der Rückhaltemaßnahmen am Oberrhein zwischen Basel und Worms. Impact of retention measures on the Upper Rhine between Basel and Worms: 1988-2018 (in German), $1 p$.

12. Neppel L., Renard B., Lang M., Ayral P.A., Coeur D., Gaume E., Jacob N., Payrastre O., Pobanz K., Vinet F., (2010). Flood frequency analysis using historical data: accounting for random and systematic errors. Hydrological Science Journal, 55(2), 192-208, doi : $\underline{10.1080 / 02626660903546092}$

13. Renard B., Sun X., Lang M. (2013). Chap3. Bayesian methods for non-stationary extreme value analysis. In "Extremes in a Changing Climate: Detection, Analysis and Uncertainty". Water Science and Technology Library. Ed. by A. AghaKouchak, D. Easterling, K. Hsu, S. Schubert, S. Sorooshian., Springer, Vol. 65, 39-95.doi: 10.1007/978-94-0074479-0 3

14. Wetter O., Pfister C., Weingartner R., Luterbacher J., Reist T., Trösch J. (2011). The largest floods in the High Rhine basin since 1268 assessed from documentary and instrumental evidence, Hydrological Sciences Journal, 56:5, 733-758, doi: $\underline{10.1080 / 02626667.2011 .583613}$

15. WSV (1975). Pegelstammbuch Maxau-Rhein. History of Rhein-Maxau gaging station (in German), 20p. 